
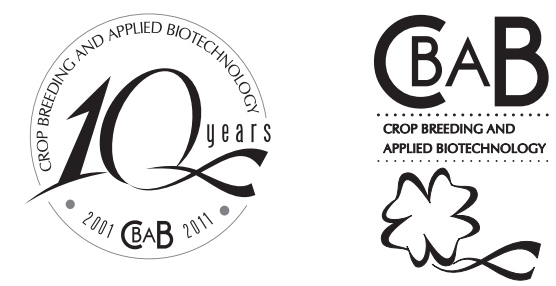

\title{
Biofuel plant species and the contribution of genetic improvement
}

\author{
Luiz Antônio dos Santos Dias ${ }^{1 *}$
}

Received 15 May 2011

Accepted 20 June 2011

\begin{abstract}
The paper analyses the puzzle of the food-energy-environmental security interaction, to which biofuels are part of the solution. It presents and discusses the contribution of genetic improvement to biofuels, with regard to the production of raw materials (oil and ethanol-producing plant species) and designs perspectives, opportunities, risks and challenges, with a special focus on the Brazilian scene. Bioethanol is a consolidated biofuel owing largely to the sugarcane breeding programs. These programs released 111 sugarcane cultivars and were responsible for a $20.8 \%$ gain in productivity of bioethanol (in $\mathrm{m}^{3}$ ha-1) between 2000 and 2009. The program of Brazilian biodiesel production, initiated in 2005, had an annual growth rate of $10 \%$ and the country is already the world's fourth largest producer. However, the contribution of breeding to biodiesel production is still modest, due to the lack of specific improvement programs for oil.
\end{abstract}

Key words: bioethanol, biodiesel, agroenergy, energy and food security, climate changes.

\section{INTERACTIONFOOD-ENVIRONMENTAL SECURITY}

The world is currently dealing with giant puzzles involving interconnected aspects related to food, energy and environmental security. It is a scenario fraught with uncertainties and challenges which is created by vertiginous population growth, increasing food demand, instability in petroleum supplies and global climate changes - all globallevel problems that tend to aggravate in the future if not addressed in the present.

The dependence on petroleum energy has become a national security issue, which is able to determine which countries will develop and which will stagnate. In the first group are nations with proper energy sources and capacity to exploit them. In the latter are countries dependent on oil imports. It should be emphasized that oil, natural gas and derivatives account for $55 \%$ of the global energy consumption. In fact, the consumption of oil and its derivatives sustained the development of the twentieth century, reaching a trillion barrels in 2005 and currently 85 million barrels a day. On the other hand, until the midtwentieth century, agriculture provided food, fiber and wood. Now, agriculture is additionally distinguishing itself as a provider of biomass energy, also called agroenergy. Agroenergy opens a wide new window of opportunity to a giant sector that seemed to have nothing more to offer. These considerations formulated by Dias et al. (2009) indicate agroenergy as part of the solution to the puzzle, particularly of the energy issue.

As everyone knows, the planet's climate is becoming warmer, with scenarios of temperature rise that may cause an intensification of droughts and floods (IPCC 2007), resulting in production losses of food and animals. The

\footnotetext{
${ }^{1}$ Universidade Federal de Viçosa, Departamento de Fitotecnia, 36.570-000, Viçosa, MG, Brazil. *E-mail: lasdias@ufv.br
} 
most likely cause for this process of global warming is the anthropogenic emission of greenhouse gases (GHG), notably of carbon dioxide and methane. It is estimated that the burning of fossil fuels accounts for $80 \%$ of these emissions (Quadrelli and Peterson 2007), although industry, agriculture and deforestation are also GHG-emitting activities.

It was in this changing scenario, in which the climate tends to become hostile to terrestrial life forms, particularly for the human species, that the population of the planet quadrupled in the twentieth century, boosting the demand for food and energy (Dias et al. 2009). Compared with 1.6 billion inhabitants in 1900 , the planet now has to sustain 6.8 billion, according to the U.S. Census Bureau (http:// www.census.gov/ipc/www/idb/worldpoptotal.php), of which $13 \%$ is undernourished. For 2030, despite the unprecedented financial crisis triggered in the fourth quarter of 2008, it is estimated that the world population will be 8.2 billion, to demand a $70 \%$ increase in food and around 17.6 btep (billion tons equivalent petroleum) energy (BEN 2007). More people are eating more and better and more energy due to the economic growth in many countries, including Brazil, Russia, India, China and South Africa (BRICS), mainly. Proof of this is that the world's food stocks are $70 \%$ below normal levels, posing a risk to the survival of humanity. It is worth remembering that Brazil is among the countries with the highest participation ( $46.4 \%$ ) of renewable energy resources in it energetic matrix, compared with a global mean of $12.7 \%$ and accounts for only $2.1 \%$ of the world energy consumption (BEN 2007, 2008).

The consequences of climate change for agribusiness begin to be debated, without preaching chaos and at this point, food, energy and climate change connect with genetic improvement. Ramalho et al. (2009), for example, discuss in detail the expected problems, especially those associated with the temperature increase and water deficit. These authors emphasize that plant breeding based on past experience has much to contribute to address the present problems. They set hopes on investing in the development of new cultivars selected under stress conditions, as the best strategy for agriculture to face changes due to climate change.

To reduce the dependence on petroleum and its derivatives, many countries are in search of alternative energy forms, such as agroenergy. Agroenergy aggregates the greatest comparative advantages: it is clean, safe, renewable, democratic, socially acceptable, and sustainable. But if on the one hand, growing energy crops means reducing regional economic asymmetries, sequester carbon, reduce GHG emissions contributing to mitigate the effects of global warming, on the other hand, for many countries it means competing with land and inputs used for food production. By the way, the fallacy of food production versus biofuel production has been adequately dissected by Branco (2009) and no longer makes sense. Anyway, as Dias et al. (2009) argue, this serious dilemma does not apply to Brazil since the country can produce both energy and food in abundance without competing with one another. The proof is that between 1976 and 2007 the productivity of the main Brazilian grain crops, 14 in all, more than doubled production. During the same 30 years, the area growing these crops increased by only $27 \%$, while yields increased by $124 \%$. As these authors stated, this dramatic increase in productivity resulting from the development and use of much agricultural technology, took place in parallel with the growth of bioethanol production in the same period. Among these technologies, there is genetic breeding, responsible for much of the success of food production.

In relation to Brazil, the most striking example of the contribution of breeding to increased food production is soybean, which increased 12-fold in only four decades, more by productivity than by area increases (Ramalho et al. 2010). This technological "miracle" was based on the development of highly productive cultivars with a long juvenile period. Soybean, originally cultivated in China where days are long, flowered early when grown in the tropics, reducing the yield. The selection of bacteria strains fixing atmospheric $\mathrm{N}$ and its inoculation into improved cultivars were also responsible for this gain in productivity. Other "miracles" of improvement were highlighted by Ramalho et al. (2010), such as of the vegetables and eucalyptus.

Perhaps the best example of successful plant breeding in the world for food production is the cereals in the UK. Studies have shown that in the last 60 years (1947 to 2006), about $90 \%$ of the increase in production of wheat and barley was due to the introduction of new cultivars. During this period, winter wheat jumped from a yield of $2.5 \mathrm{tha}^{-1}$ to the current $8.3 \mathrm{tha}^{-1}$. Non-varietal factors such as nitrogen fertilization, use of agrochemicals, growth regulators and mechanization were also fundamental to ensure the productive potential of the new varieties (BSPB 2008). The differential of these studies is that the contribution of genetic improvement to the increased productivity was actually quantified. 


\section{BIOFUELSANDTHE CONTRIBUTION OF PLANT BREEDING}

The success of genetic improvement in domestic food production is beginning to have some impact as well on the production of biofuels - ethanol and biodiesel especially on the first. It is worth remembering that biofuels are liquid or gaseous fuels produced from renewable, animal or plant-based organic matter, called biomass, for transportation or heating. It should also be remembered that fossil fuels were produced by nature in the remote past, from organic sediments. Therefore, the new biofuels are produced by the new agriculture sector which is agroenergy referred to in the previous section. We are speaking about an giant market. The International Energy Agency estimates that by 2050, biofuels will account for $27 \%$ of the fuel consumed for transportation, replacing diesel and kerosene, avoiding the emission of 2.1 Gtonnes of $\mathrm{CO}_{2}$ per year, when produced in a sustainable way (IEA 2011).

Hereafter, bioethanol and biodiesel will be described in detail, dealing specifically with each alcohol and oilseed species, classified here as conventional (already proven) or promising (in test phase), from the point of view of the contribution of genetic improvement. The contributions of Brazil were emphasized, in view of the position of the country as world leader in the biofuels sector. Particularly the contribution of genetic improvement in the 2000s (growing seasons 1999/00 to 2008/09) will be portrayed, since this period represents the maturity of Brazilian agriculture, which has been consolidated since then.

\section{Bioethanol}

The world bioethanol production reached 85 billion liters in 2010, according to the Global Renewable Fuels Alliance (GRFA, www.globalrfa.org) - the international federation that represents $65 \%$ of global biofuel production of 44 countries. Six of them plus one block (USA, Brazil, European Union, Argentina, Canada and China) accounted for $98 \%$ of this production. Only $10 \%$ of the world production is destined for the international market and Brazil accounts for $90 \%$ of the world exports (CEPAL 2011). In the next 10 years, it is estimated that the global bioethanol production will grow by $25 \%$, while Brazil's production is expected to grow by $45 \%$ (USDA 2011). Brazil produced 26.1 billion liters of bioethanol (anhydrous and hydrated) in 2009 and exported 3.3 billion liters. The average annual growth rate of Brazilian production from 2000 to 2009 was $10.4 \%$ (ANP 2010). In energy terms, one liter of bioethanol contains $66 \%$ of the energy of a liter of gasoline.

About $36 \%$ of the world bioethanol production was based on sugarcane (mainly from Thailand, Brazil, Colombia, and India), $58 \%$ is produced from corn (U.S., Canada and China, basically) and the remaining $5 \%$ from other energy crops. It is important, however, to distinguish Brazilian bioethanol from the others. This biofuel is produced from sugarcane, not a food species, in a sustainable process. The U.S. bioethanol, aside from competing with the global food production, for being corn-based, is still produced in an inefficient and uneconomic way, maintained by strong subsidies. The energy efficiency of Brazilian bioethanol production is 5.5 times higher, at half the cost of U.S. bioethanol (Dias et al. 2009). Currently, bioethanol and sugar are extracted from sugarcane juice and bioelectricity is produced from bagasse and straw. The sustainability of this process has advanced to such a degree that the sugar and alcohol mills of the past are today biorefineries of bioethanol, sugar and bioelectricity. It is a significant advance. Additionally, after two years of research, the U.S. Environmental Protection Agency has classified sugarcane bioethanol as "advanced biofuel" with a proven reduction in $\mathrm{GHG}$ emissions of $61 \%$ compared to gasoline. In the same study, this percentage was three times higher than of bioethanol from U.S. corn (21\%) (IEA 2011).

The Brazilian bioethanol has gained importance with the Pró-álcool, the official program of partial replacement of gasoline, launched in 1975 in response to the soaring oil prices in the so-called first crisis. After the second oil price crisis in 1979, the program was consolidated with the launch of biofuel cars (gasoline and/or bioethanol), also called "flex-fuel" in 2003 (Dias et al. 2009). As of July 2007, with the publication of Regulation No. 143/MAPA, all gasoline sold in Brazil came to contain $25 \%$ anhydrous bioethanol. In 2010, the Brazilian consumption of ethanol exceeded gasoline. On April 29, 2011, the provisional measure 532 reclassified bioethanol as an industrial (no longer agricultural) product and constituted the national agency for petroleum, natural gas and biofuels ANP (www.anp.gov.br) as responsible for the entire production, processing and supply chain of biofuels (i.e., bioethanol and biodiesel). The success of world-renowned Brazilian bioethanol is largely the success of sugarcane - the grass crop brought here almost 500 years ago. And the success of the sugarcane crop is mostly due to genetic improvement. 


\section{Sugarcane}

It is estimated that in the of 2010/11 growing season Brazil produced 651 million tons of sugarcane harvested from 8.8 million hectares (AGRIANUAL 2011), half of which was used for sugar and the other half for bioethanol production. This yield was 9.5 times higher than in the $1975 / 76$ season. In turn, the average sugarcane yield of $46.8 \mathrm{t} \mathrm{ha}^{-1}$ in 1975 increased to $77.5 \mathrm{tha}^{-1}$ in 2008 (BRASIL/ MAPA 2009). But the actual contribution of improvement to the increased yield of Brazilian bioethanol is indicated by the yield of this biofuel. In this case, productivity gains in bioethanol in the 2008/09 growing season, compared to $1999 / 00$, were $20.8 \%$ and $13.4 \%$ in terms of $\mathrm{m}^{3} \mathrm{ha}^{-1}$ of sugarcane and $\mathrm{L}^{-1} \mathrm{t}$ of crushed sugarcane, respectively (Table 1). If the Brazilian production of bioethanol is victorious, this is not equally true for the rest of the world. While the productivity of Brazilian bioethanol is $6.33 \mathrm{~m}^{3}$ $\mathrm{ha}^{-1}$, it is $4 \mathrm{~m}^{3} \mathrm{ha}^{-1}$ of the North American corn bioethanol and $1.8 \mathrm{~m}^{3} \mathrm{ha}^{-1}$ of the European wheat bioethanol (BNDES/ CGEE 2008). Moreover, one must not forget that corn and wheat are base components of the human and animal diet. The United States has earmarked $30 \%$ of its maize output for bioethanol production, which drives up the world food price level in general, and in particular of meat and cereals.

Surely for no other energy plant species genetic breeding has been as successful as for sugarcane. In 1991, seven Brazilian universities (UFPR, UFSCar, UFV, UFRRJ, UFS, UFAL, and UFRPE) took over the directive body and infrastructure of the former Planalsucar, and joined in an interuniversity research network for the development of the sugar alcohol sector, called RIDESA (www.ridesa.com.br). Under agreements signed with biorefineries, a broad improvement program was initiated. After 20 years of improvement, RIDESA has released more than 65 cultivars of the RB label series, planted in $58 \%$ of Brazil's cane fields. The average time until the release of a new sugarcane cultivar is 11 to 13 years. The Brazilian sugarcane cultivars with commercial value are developed by three main programs: the traditional breeding program of the Agronomy Institute of Campinas - IAC (www.iac.sp.gov.br), the Sugarcane Technology Center - CTC (www.ctcanavieira. com.br/site/) the former Copersucar, and the universities that constitute RIDESA. The youngest program, the Canavialis (www.canavialis.com.br/src/), was launched in 2004 and has not released any cultivar to date, and was acquired in 2008 by the company Monsanto (Barbosa and Silva 2010).
Thanks to the breeding programs, the MAPA (Ministry of Agriculture, Livestock and Supply) had registered 111 sugarcane cultivars by 2009 (Table 1).

So far, this was only the first-generation bioethanol. But sugarcane technology is advancing. The straw or trash (shoot leaves) represents $15 \%$ of the weight of the cane stalks at harvest, or $12 \%$ when dry. It also represents $40 \%$ of non-utilized energy. Behind the banning of sugarcane burning at harvest was the idea of forcing the use of this great wasted energy potential. Even if the trash is not collected at harvest, it can be dried in the field and used for both direct combustion and conversion into thermal or electrical energy, as for transformation into liquid fuel, as soon as the technology of cellulose digestion (lignocellulose hydrolysis) is commercially dominated. Large investments of the U.S. and European Union are being made in this cellulosic or second-generation bioethanol. The energy efficiency will become even greater when compared with the current technology of sacarose transformation (Matsuoka et al. 2010).

\section{Biodiesel}

Since 2000, global biofuel production was on the rise at an annual rate of $10 \%$, and reached 90.1 billion liters in 2009. Of this total amount, $82 \%$ correspond to ethanol and $18 \%$ to biodiesel. The biodiesel market is not only 5.6 times smaller, but also highly concentrated. Only five countries produce nearly two thirds of the global production: USA (14.3\%), Argentina (13.1\%), Germany (12.6\%), France (12\%), and Brazil (9.7\%) (CEPAL 2011). The energy content of biodiesel is equivalent to $88-95 \%$ of petrodiesel.

In Brazil, the Pro-Alcohol, launched in 1975, had an exclusively economic focus, aiming at the partial replacement of gasoline by bioethanol, whereas the orientation of the national program for biodiesel production and use, the PNPB (Law 11.097, on January 13, 2005 ) is social and environmental, not merely economic. From a social standpoint, PNPB was structured to generate employment and income, with the expectation that every 1 $\%$ of petrodiesel replaced with biodiesel would generate 45,000 jobs in the field and every job in the field would generate three others in the city. From the environmental point of view, the program was launched to promote another biofuel, the biodiesel, with a reduced burden of GHG emissions compared to petrodiesel (NAE 2005). The PNPB established a mixture percentage of $2 \%$ biodiesel (B2) with petrodiesel, authorized from 2005 to 2007, and 


\section{LAS Dias}

mandatory as of 2007. Since then, this percentage has gradually increased and represents $5 \%$ since January 2010 (B5). The Brazilian biodiesel production in 2010 was 2.4 billion liters, versus an installed capacity in the same year of around 5.8 billion liters (ANP 2011). This production of biodiesel is important to reduce petrodiesel imports. In 2008, the use of B2 biodiesel in Brazil prevented petrodiesel imports of 1.1 billion liters, resulting in foreign currency savings of U.S. \$ 976 million. In 2009, Brazil imported 3.5 billion liters of petrodiesel, with expenses of 1.5 billion dollars (ANP 2010).

Among the most important conventional annual oilseed species in Brazil are soybean (Glycine max), sunflower (Helianthus annuus), upland cotton (Gossypium hirsutum), peanut (Arachis hypogeae) and castor bean (Ricinus communis). In turn, the most important conventional perennial oilseed species in Brazil is oil palm (Elaeis spp.). New promising perennial oilseeds are jatropha (Jatropha curcas) and macaw (Acrocomia aculeata) (Table 1). From January 2010 to February 2011, $83.97 \%$ pure national biodiesel (B100) was produced from soybean oil, beef fat $12.47 \%, 2.7 \%$ of cottonseed oil, $0.29 \%$ of pork fat, $0.54 \%$ of frying oil used, and the remaining $0.70 \%$ from other fatty materials such as oils from sunflower, peanut and castor bean (ANP 2011). This strong concentration on one raw material creates temporary bottlenecks, since large producers and large companies dominate the soybean production, and this oilseed is the basis of the most frequently consumed oil and meal in the world.

Certainly the candidate list for raw material for biodiesel production includes over 100 species. But a high oil content is not enough to qualify a species. An organized supply chain, large-scale production and consolidated agrotechnological package must also be available. Dias and Missio (2009) reported that less than 20 of these could be commercially explored in the short/medium term. They all have advantages and disadvantages, making the choice difficult for breeders who want to start an oilseed breeding program. Among the promising species, Dias and Missio (2009) selected the 16 most important to assess the potential for genetic improvement and developed the so-called $\mathrm{M}$ index - an index of the potential for improvement of the oilseed for biodiesel production. The $\mathrm{M}$ index was based on the following important criteria for a breeding program: production system, registered cultivars, agroclimatic zoning, breeding level, oil content, oil productivity, oil use in food, and vegetative propagation. To calculate the $\mathrm{M}$ index, each criterion was scored and the scores in sequence were multiplied by their respective weights. So, this $\mathrm{M}$ index can range from 0.5 (species with low potential) to 2.0 (species with high potential for oil improvement). In general, $\mathrm{M}>1.3$ qualifies an oilseed crop as promising for an improvement program targeting biodiesel production. The importance of the M index is related to the fact that the country must concentrate the scarce research resources on plants with greatest potential for improvement.

\section{Soybean and cotton}

Soybean and cotton have the same average oil content (about $18 \%$ ). Nevertheless, in the last decade, the productivity of cottonseed oil increased by $64 \%$ and of soybean oil by $14 \%$ (Table 1 ). These gains can however not be interpreted directly. Contrary to what the gains seem to indicate, no oilseed breeding program was as successful as that of soybean, although it was primarily focused on grain yield for high protein content. By 2009, MAPA had registered more than 600 soybean cultivars (Table 1). In half a century of research, in particular of breeding, the cultivation of soybean in Brazil became possible by cultivars developed for high yield and wide climate adaptability at lower latitudes and resistant to the major pests and diseases. However, the increase in soybean yield was significant in the 1970s and 1980s, modest in the 2000s and virtually stagnant between the growing seasons of 2002/03 and 2008/09 (BRASIL/MAPA 2009). In the last decade, 32.3 million tons ( $\mathrm{t}$ ) produced on 13.5 million hectares (ha) increased to 57.6 million tons grown on 21.5 million ha. In the same period the grain yield increased from 2395 to $2674 \mathrm{~kg} \mathrm{ha}^{-1}$.

Although outstanding oil producers for biodiesel according to the PNPB, the main commercial destination of soybean and cotton is another. Soybean is the main protein source $(38 \%)$ in the milling industry for food and feed and also for the processed and semi-processed food industry (Sediyama et al. 2009). Therefore, most soybean breeding programs have focused on raising the protein content, which is known to be genetically and inversely correlated with the oil content. Similarly, the primary interest in cotton is the textile fiber, while the kernel is exploited as commercial spin-off for oil production.

Both oilseeds have well-developed agrotechnological package, involving the availability of a large number of cultivars, soil-climate zoning and an established production system. From planting to harvest of the crops, intense and high-tech mechanization is used and the storage and 
Biofuel plant species and the contribution of genetic improvement

Table 1. List of the alcohol species and conventional and promising oil species and their respective yield gains

\begin{tabular}{|c|c|c|c|c|}
\hline \multicolumn{5}{|c|}{ Conventional alcohol species } \\
\hline & \multicolumn{4}{|c|}{$\begin{array}{l}\text { Bioethanol production } \\
\left(\mathrm{m}^{3} \mathrm{ha}^{-1} ; \mathbf{L t}^{-1}\right)\end{array}$} \\
\hline & 1999/00 & 2008/09 & Yield gain $(\%)$ & Cultivars registered by MAPA until 2009 \\
\hline \multirow{2}{*}{$\begin{array}{l}\text { Sugarcane } \\
\text { Maize }\end{array}$} & $5.24 ; 76.8$ & $6.33 ; 87.1$ & $20.8 ; 13.4$ & 111 \\
\hline & & $4 ; 440.0$ & & \\
\hline \multicolumn{5}{|c|}{ Conventional oil species } \\
\hline & \multicolumn{4}{|c|}{ Oil production $\quad\left(\mathrm{t} \mathrm{ha}^{-1}\right)$} \\
\hline & $1999 / 00$ & 2008/09 & Yield gain(\%) & Cultivars registered by MAPA until 2009 \\
\hline So ybean ${ }^{1}$ & 0.42 & 0.48 & 14 & 604 \\
\hline Cotton ${ }^{1}$ & 0.25 & 0.41 & 64 & 62 \\
\hline Sunflower $^{2}$ & 0.91 & 0.76 & -19 & 154 \\
\hline Peanut $^{3}$ & 0.74 & 1.16 & 57 & 14 \\
\hline Castor bean ${ }^{3}$ & 0.25 & 0.34 & 36 & 21 \\
\hline Oil palm & 2.60 & 2.70 & 4 & 8 \\
\hline \multicolumn{5}{|c|}{ Promising oil species } \\
\hline Jatropha $^{4}$ & & 1.9 & - & - \\
\hline Macaw palm ${ }^{5}$ & & 5.0 & - & - \\
\hline \multicolumn{5}{|c|}{$\begin{array}{l}\text { Sources: BRASIL (2005); BNDES/CGEE (2008); BRASIL/MAPA (2009); ANP (2010). } \\
{ }^{1} \text { Estimated oil production, based on grain yield, considering } 18 \% \text { oil; } \\
{ }^{2} \text { Estimated oil production, based on grain yield, considering } 54 \% \text { oil; } \\
{ }^{3} \text { Estimated oil production, based on grain yield, considering } 45 \% \text { oil; } \\
{ }^{4} \text { Estimated oil production, based on grain yield, considering } 38 \% \text { oil; } \\
{ }^{5} \text { Estimated oil production, based on kernel yield, considering } 20-30 \% \text { oil. }\end{array}$} \\
\hline
\end{tabular}

marketing structure of the respective agro-industries are satisfactory. Despite all these advantages, the availability of oil from these two commodities, as Roscoe (2008) warned, is very vulnerable due to fluctuations in the protein and fiber supply market, besides, soybean oil is edible and used in the food industry. The world production of soybean and cottonseed oil in 2007/08 was 37.6 (AGRIANUAL 2011) and 4.88 million tons (BRASIL/MAPA 2009), respectively. The increase in cottonseed oil production is worth mentioning, with an increment of $23 \%$ as of 2004/ 05 , which was stabilized in the following growing seasons.

In Brazil, soybean oil is the most consumed (90\%), followed by cottonseed oil (4.5\%). The U.S. and Argentina, respectively, the first and third largest soybean producers in the world, also use soy as raw material for biodiesel production. It is worth mentioning that redirecting part of the soybean output to produce oil for biodiesel generates a demand pressure on the prices of food and meat products for which this oilseed is used.

The physical and chemical properties of plant oils and animal fats are determined by the type and proportion of fatty acids and are transferred to the biodiesel (Knothe 2005). Soy oil has a lower viscosity than most plant oils, facilitating injection into the combustion chamber. However, the high number of double bonds in its carbon chain reduces the oxidative stability of this biodiesel (Reis 2009), although the addition of antioxidants to biodiesel solves this problem. Another approach to overcome the low oxidative stability is the development of soybean cultivars with a higher ratio of oleic/linoleic acid, which is being pursued in research.

\section{Sunflower and peanut}

Sunflower and peanut produce noble and expensive oils on the market for human consumption and peanut oil, in particular, is the world's most expensive. Their cakes and bran are rich in protein and used for animal feed. Despite developed agrotechnological package, these two oils are not produced yet on a sufficiently large scale to meet the demand of a program the size of PNPB.

Currently, peanut has been planted by biorefineries during the renewal stage of the sugarcane plantations. 


\section{LAS Dias}

Companies are making profit by selling peanuts for fresh human consumption, as snacks in laminated aluminum foil packaging. Still, the increase in demand has triggered a significant increase in oil productivity in the last decade (Table 1). But since sunflower and peanut are noble oils for human consumption, they will hardly become economically feasible for biodiesel production, except if the profitability of the latter should exceed the current commercial destination of the two.

\section{Castor bean}

When the PNPB was launched in 2005, castor bean was appraised as key oilseed for biodiesel production. This expectation was however not met in view of the difficulties to transfer the entire agrotechnological package the production of the species implies to the reality of small farms in the semi-arid areas of Brazil. Seed yields of improved cultivars of more than $1500 \mathrm{~kg} \mathrm{ha}^{-1}$ (Freire et al. 2001 ) contrast with seed yields of $300 \mathrm{~kg} \mathrm{ha}^{-1}$ on family farms in the Northeast of Brazil. Castor bean has been improved in the country with success and pioneering spirit since 1936 by the Agronomic Institute of Campinas, which introduced the trait of fruit indehiscence in commercial cultivars, making a single harvest possible. Currently, universities, Embrapa and state research institutions also have their breeding programs (Freire et al. 2001). As of 2009, 21 varieties had been registered by MAPA (Table 1).

The low technological level of production, lack of technical assistance for cultivation, use of unimproved seed and lack of a supply chain and logistics that would unite the thousands of small castor bean farmers all across the semi-arid region of Brazil, are factors that prevent castor oil from reaching a production scale that would meet the demands of PNPB. Additionally, castor oil is actually too noble to be burned in engines in the form of biodiesel. This oil, consisting of more than $90 \%$ of ricinoleic acid, is one of the most versatile natural products in the world and reaches high prices in the lubricant market and wide applicability in the industry of petroleum and chemical resins (Freire 2001). For biodiesel, castor oil has yet another restriction, of chemical nature, which is its high viscosity.

\section{Oil palm}

Oil palm is the only perennial oilseed for which conditions are given to meet the substantial biodiesel demand of PNPB in the medium/long term (BRASIL 2005). The agrotechnological package for cultivation of the species are given by the availability of hybrid cultivars
(Table 1) with high-yielding bunches, and 10 million hectares of land suitable for oil palm cultivation in Brazil, especially in the states of Pará and Southern Bahia. Despite this potential, Brazil has only 57,000 hectares under oil palm (BRASIL/MAPA 2009) and imports oil to supplement its demand. Incidentally, palm oil is extracted from the pulp and kernels. The pulp oil is used in the manufacture of margarine, ice cream and cookies, replacing hydrogenated fat while the surplus can be used to produce biodiesel. Agropalma, a company in Pará with 40,000 hectares of oil palm, came to produce biodiesel from palm oil sludge. The palm kernel oil is noble and used in the cosmetics industry.

The possibility of self-sufficiency of Brazil in palm oil production and even in the production of biodiesel from the excess production requires heavy investments. Government incentives and financing are needed to enable private companies to invest in the expansion of oil palm cultivation in Brazil.

\section{Jatropha}

Jatropha combines three major advantages compared to other oilseeds: it is a non-food species, the grain and oil yield potential is good $\left(5 \mathrm{t} \mathrm{ha}^{-1}\right.$ and $1.9 \mathrm{t} \mathrm{ha}^{-1}$, respectively) (Table 1) and the oil has excellent properties for biodiesel production, for example a high content of oleic acid. In addition, the species has several secondary benefits e.g., it is perennial, can produce for up to 40 years and is drought-tolerant. Despite these advantages, jatropha is still not more than a promise, as there are no agroecological zoning or cultivars available, agrotechnological knowledge is limited and domestication in an initial stage. Research on this species is advancing in all fields of agrotechnological knowledge, since development agencies and private companies are interested. China and India claim to have about 2.6 million ha of jatropha (Fairless 2007). In Brazil, however, the commercial planting of Jatropha curcas is an economically risky activity that is not advisable for farmers until research provides cultivars. Once this occurs, surely intercrops of jatropha x pasture and jatropha $\mathrm{x}$ annual food/oil species will be better options than single crops or monoculture (Dias et al. 2008).

The group Agroenergia Federal University of Viçosa is developing research with jatropha ( $M$ index $=1.4$ ), macaw $(\mathrm{M}=1.3)$ and other annual species for intercropping with these two perennial oilseeds. In the case of jatropha, an extensive program of pre-breeding and breeding is being conducted, coupled with related areas such as plant pathology, entomology, seed technology, reproductive biology, mineral nutrition, socio-economics and oil chemistry. 


\section{Macaw}

Macaw is another promise, similar to jatropha. It is a widely distributed palm tree in the dry regions of tropical America (Henderson et al. 1995). Its performance as oilseed is similar to oil palm, which justifies its popular name "dendê mineiro" (oil palm from the state of Minas Gerais). Lleras and Coradin (1985) report that macaw can produce $5 \mathrm{t}$ of oil (oleic-palmitic acid) (Table 1) and 1.4 tons of lauric

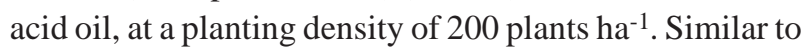
oil palm, macaw oil sours quickly (in less than $48 \mathrm{~h}$ ) if not processed and is pressed from the pulp (suitable for biodiesel) as well as from the kernels.

As in the case of jatropha, there are no macaw palm cultivars or specific agrotechnological information available for commercial exploitation. Although an accelerated germination process (32 days with $85 \%$ germination) was developed and patented by researchers of the Federal University of Viçosa (Motoike et al. 2007), other bottlenecks persist, e.g., the long juvenile period (seven years to start production), irregular fruit maturation and inexistence of harvesting machines.

\section{RISKS, OPPORTUNITIESAND PROSPECTS OF BIOFUEL PRODUCTIONFORIMPROVEMENT}

There are risks, opportunities and prospects for genetic improvement associated with the development of biofuels, which vary with the raw material and with the conversion process used in the agroindustry plant, and even with the effective regulatory framework. The Economic Commission for Latin America and the Caribbean-CEPAL, recognizes that although the climate conditions are favorable, land availability abundant and labor force cheap, the advance of bioethanol in Brazil is remarkable. The institution attributes this progress to the great efforts in $\mathrm{R}$ \& D (Research and Development) of government and private sectors to increase sugarcane yields, to optimize the production process and use the bagasse for cogeneration of electricity. Also according to CEPAL, all this combined effort has made Brazil the world's most efficient country in bioethanol production, the only nation able to compete with gasoline without direct subsidies (US\$ 0.30 per liter in 2007) and one of the most efficient in reducing GHG so the country is expected to continue as the main exporter of bioethanol. Nevertheless, Brazil should be aware of future competing countries that are on the track of reducing production costs.
There is a need of "commodification" of bioethanol and biodiesel, not only to create a stable market, free of protectionism, but also to encourage countries to shift their energy matrix towards renewable, sustainable and clean sources. The U.S. and EU, for example, aside from paying subsidies to their producers, now beckon with the establishment of technical barriers to imported biofuels, acting as a trade barrier. The European norm EN 590 - Diesel, for example, limits the use of soybean oil and palm oil for biodiesel (CEPAL 2011), with the effect of a trade barrier. The U.S. government pays \$ 11 million annual subsidies to corn growers to produce ethanol (Branco 2009). This boosts the price of the corn in the international market, since corn is a basic component of human and animal diet. Moreover, EU and U.S. protect their domestic markets from biofuels, establishing tariff barriers to Brazilian ethanol. The current fees Brazilian exporters of the product to the North American market are charged with represents an ad valorem tax of $2.5 \%$ applied in conjunction with another specific toll of $\$ 0.54$ per gallon of ethanol. The EU taxes Brazilian bioethanol at \$ 1 per gallon, equivalent to $60 \%$ of its price (Branco 2009). Protectionism of any kind is a serious risk for the biofuel industry and should be criticized.

In the production of first generation biofuels, the production costs consist mainly of the raw material and can vary from $60 \%$ in the case of bioethanol from sugarcane to $75 \%$ for biodiesel from oilseeds. This has two consequences. The first is the possibility of increasing the profitability of the supply chain by reducing the production costs of raw materials. The second is the opportunity to expand the job market for breeders assigned to increase the conversion efficiency of raw material into biofuels. The competence in genetic improvement in Brazil has to be enhanced by allocating more resources to traditional breeding, as suggested by Ramalho et al. (2010). More than that, the country needs to attract more research institutions and breeders to the biofuel industry to maintain its global leadership position. It is worth mentioning that the current productivity levels of sugarcane and oil palm, for example, are far below their potential. The production potential for sugarcane (stalks) is estimated at $350 \mathrm{t} \mathrm{ha}^{-1}$ and for oil palm (oil) at $6 \mathrm{t} \mathrm{ha}^{-1}$. Exploiting more of this production potential would mean to produce more bioethanol and biodiesel without expanding the planting area and with a minimal environmental impact. This scenario indicates the long way the genetic improvement of sugarcane and of some oilseed species will still have to go. The transformation of sugarcane in terms of 


\section{LAS Dias}

biotechnology is easy, although no genetically modified cultivar has been released yet. According to Borém et al. (2010), studies on genes for resistance to viruses, insects, and drought, besides other factors, are underway. Another important and little discussed area of activity in the bioethanol sector is the development of its alcochemistry, so as not to sustain the country's position as commodity exporter of bioethanol only.

More resources should be earmarked for research on oilseed species, such as jatropha and macaw. It is estimated that macaw in monoculture has a potential oil production of $5 \mathrm{t} \mathrm{ha}^{-1}$, while jatropha can produce $2.0 \mathrm{tha}^{-1}$. However, intercropped they can produce up to $7.0 \mathrm{t} \mathrm{ha}^{-1}$ oil with excellent characteristics for biodiesel (Dias et al. 2008). The advantage of the macaw-jatropha intercropping system is energy densification, ie, the ability to produce at least $50 \%$ more oil in the same area. But there are other important advantages to energy densification, such as a regular supply of raw materials, practically all year long, since macaw produces from October to May and jatropha from December to May. This uninterrupted production eliminates shut-off periods of the factory and reduces the dependence on the unstable raw material market. In addition, the entire production of the intercropping system can be optimized, by destining jatropha cake for soil fertilization and macaw cake for animal feed. Moreover, to the revenue from the oil production and exploitation of the cakes, the revenue from the sale of milk, meat and leather from dairy and beef cattle can be added, in the case of crop-livestock integration. The intercropping system seems very promising in the neutralization of greenhouse gases, which one day may possibly be capitalized as carbon credits on the international market.

It is worth mentioning the advance of oilseed cultivation, e.g., of safflower, crambe, rapeseed and camelina, in the second growing season in the agribusiness in western Brazil. Research is called for to support this initiative of the producers. Other plant species are worth citing that may facilitate bioethanol production on family farms, e.g., sweet potato and cassava, with which smallholders are familiar, as mentioned by Dias et al. (2009). Sweet potato, for example, can produce $160 \mathrm{~L}$ bioethanol per ton of tubers. Regional or local programs to encourage bioethanol production could be implemented to involve farmers in a cooperative system. This would certainly be a powerful instrument of reducing regional economic disparities and poverty, as well as of expanding employment and income.

Finally, the government - the mentor and promoter of PNPB - must be aware of possible needs of course corrections of the program. Ribeiro et al. (2011) studied a sample of 17 factories, producing $39 \%$ of the national biodiesel output in 2008, and found that $78 \%$ of the factory directories believed in a positive outlook for the energy sector. However, the same respondents named several challenges such as high oilseed production cost, undermining the continuous production of biodiesel; bureaucratic processes; the market prices for biodiesel sale, which are still unprofitable; market regulations by auctions; the difficulties of meeting of the so-called 'Social Fuel Seal' (SCS); and the lack of raw material on a large scale to keep the factory operating; the uncertainty about the future situation of the biodiesel market; the difficulty of introducing new raw materials, in the case of Southern Brazil; the fact that the tax abatement granted by the MDA does not pay the cost of acquiring the SCS; the insufficiency of family farming to meet the total demand of raw material this industry requires; the monopoly of Petrobras (purchase and sale); the control of Brazilian agriculture by multinational corporations; the ban on direct sales of biodiesel to distribution companies, forcing the refineries to offer their production at auctions regularized by ANP and Petrobras; the fact that biodiesel is sold and bought on an auction market, through contracts for future delivery in formal bids, so that the main raw material (soybean) is exported at current market prices; the difficulty of competing with companies that participate in the auction and have the SCS, that is, that pay less taxes because they hire family farmers to produce biodiesel, mostly from castor oil; and the uncertainty about the prices, since the market is regulated by auctions. 


\title{
Plantas produtoras de biocombustíveis e a contribuição do melhoramento genético
}

\begin{abstract}
RESUMO - $O$ artigo analisa o quebra-cabeças que se tornou a interação segurança alimentar x energética $x$ ambiental, e os biocombustíveis são parte da solução. Apresenta e discute a contribuição do melhoramento genético para os biocombustíveis, com referência a produção de matérias-primas (espécies alcooleiras e oleaginosas) e projeta perspectivas, oportunidades, riscos e desafios, com ênfase no cenário brasileiro. O bioetanol é um biocombustível consolidado graças, em grande medida, ao programas de melhoramento da cana. Esses programas foram responsáveis pelo lançamento de 111 cultivares de cana e por um ganho de 20.8 $\%$ na produtividade de bioetanol ( $\mathrm{em} \mathrm{m}^{3} \mathrm{ha}^{-1}$ ), no período 2000-2009. O programa brasileiro de produção de biodiesel, lançado em 2005, teve crescimento anual acentuado de $10 \%$ e o País já é o quarto maior produtor mundial. Todavia, a contribuição do melhoramento para produção de biodiesel é ainda modesta, em razão da escassez de programas de melhoramento específicos para óleo.
\end{abstract}

Palavras-chave: bioetanol, biodiesel, agroenergia, segurança energética e alimentar, mudanças climáticas.

\section{References}

AGRIANUAL (2011) Anuário da agricultura brasileira. AgraFNP, São Paulo, 482p.

ANP - Agência Nacional de Petróleo, Gás Natural e Biocombustíveis (2010) Anuário estatístico brasileiro do petróleo, gás natural e biocombustíveis. ANP, Rio de Janeiro, 227p.

ANP - Agência Nacional de Petróleo, Gás Natural e Biocombustíveis (2011) Boletim mensal do biodiesel. ANP, Rio de Janeiro, 9p.

Barbosa MHP and Silveira LCI (2010) Melhoramento genético e recomendação de cultivares. In Santos F, Borém A and Caldas C (eds.) Cana-de-açúcar: bioenergia, açúcar e álcool: tecnologia e perspectivas. Suprema, Visconde do Rio Branco, p. 313-331.

BEN - Balanço Energético Nacional (2007) Resenha energética brasileira: exercício 2006. MME, Brasília, 14p.

BEN - Balanço Energético Nacional (2008) Resenha energética brasileira: exercício 2007. MME, Brasília, 14p.

BNDES/CGEE (2008) Bioetanol de cana-de-açúcar: energia para o desenvolvimento sustentável. BNDES, Rio de Janeiro, $316 \mathrm{p}$.

BSPB (2008) New varieties underpin UK cereal yield growth. Available at <http://www.bspb.co.uk/newsarticle_2008_06_10a. html $>$ Assessed on Nov. 6, 2009.

Borém A, Silva JA and Diola V (2010) Biologia molecular e biotecnologia. In Santos F, Borém A and Caldas C (eds.) Canade-açúcar: bioenergia, açúcar e álcool: tecnologia e perspectivas. Suprema, Visconde do Rio Branco, p. 334-355.

Branco LGB (2009) Biocombustíveis brasileiros e o mercado internacional: desafios e oportunidades. Revista CEI 13: 39-48.
BRASIL/MAPA (2009) Anuário estatístico da agroenergia. MAPA/ACS, Brasília, 160p.

BRASIL (2005) Plano nacional de agroenergia. MCT, Brasília, $120 \mathrm{p}$.

CEPAL (2011) Estudio regional sobre economía de los biocombustibles 2010: temas clave para los países de América Latina y el Caribe. CEPAL, Santiago, 100p.

Dias LAS and Missio RF (2009) Biodiesel: oportunidade para o melhoramento de plantas. In XIII Simpósio de atualização em genética e melhoramento de plantas. GEN/UFLA, Lavras, p. 48-56.

Dias LAS, Missio RF, Ribeiro RM, Freitas RG and Dias PFS (2009) Agrocombustíveis: perpectivas futuras. Bahia Análise \& Dados 18: $539-548$.

Dias LAS, Muller M and Freire E (2008) Potencial do uso de oleaginosas arbóreas em sistemas silvipastoris. In Fernandes EM, Paciullo DSC, Castro CRT, Muller MD, Arcuri PB and Carneiro JC (org.) Sistemas agrossilvipastoris na América do Sul: desafios e potencialidades. Embrapa Gado de Leite, Juiz de Fora, p. 283-314.

Fairless D (2007) The little shrub that could - maybe. Nature 449: 652-655.

Freire RMM (2001) Ricinoquímica. In Azevedo DMP and Lima EF (eds.) O agronegócio da mamona no Brasil. Embrapa Informação Tecnológica, Brasília, p. 295-335.

Henderson A, Galeano G and Bernal R (1995) Field guide to the palms of the Americas. Princeton University, New Jersey, p.166-167.

IEA - International Energy Agency (2011) Technology roadmap: biofuels for transport. IEA, Paris, 56p. 


\section{LAS Dias}

IPCC (2007) Climate change - the physical science basis: summary for policymakers. IPCC, Geneva, 18p.

Knothe G (2005) Dependence of biodiesel fuel properties on the structure of fatty acid alkyl esters. Fuel Processing Technology 86: 1059-1070.

Lleras E and Coradin L (1985) Palmeras nativas como oleaginosas: situación actual y perspectivas para América Latina. In Forero LE (ed.) Informe del seminário taller sobre oleaginosas promisorias. Asociación Interciencia/Asociación Colombiana para el Avance de la Ciencia, Bogotá, p. 92-143.

Matsuoka S, Bressiani J, Maccheroni W and Fouto I (2010) Bioenergia da cana. In Santos F, Borém A and Caldas C (eds.) Cana-de-açúcar: bioenergia, açúcar e álcool: tecnologia e perspectivas. Suprema, Visconde do Rio Branco, p. 487-517.

Motoike SY, Lopes FA, Sá Júnior AQ, Carvalho M and Oliveira MAR (2007) Processo de germinação e produção de sementes pré-germinadas de palmeiras do gênero Acrocomia. (Protocolo INPI 014070005335).

NAE - Núcleo de Assuntos Estratégicos da Presidência da República (2005) Biocombustíveis. NAE/Secretaria de Comunicação de Governo e Gestão Estratégica, Brasília, 233p. (Cadernos NAE, 2).

Quadrelli R and Peterson S (2007) The energy-climate challenge: recent trends in $\mathrm{CO}_{2}$ emissions from fuel combustion. Energy Policy 35: 5938-5952.
Ramalho MAP and Dias LAS (2009) Genetic plant improvement and climate changes. Crop Breeding and Applied Biotechnology 9: 189-195.

Ramalho MAP, Toledo FHRB and Souza JC (2010) Melhoramento genético de plantas no Brasil. In Ramalho MAP, Toledo FHRB, Souza JC and Teixeira RA (eds.) Competências em melhoramento genético de plantas no Brasil. CGEE/ SBMP, Viçosa, p. 16-38.

Reis C (2009) Biodiesel. In Sediyama T (ed.) Tecnologia de produção e usos da soja. Mecenas, Londrina, p. 303-314.

Ribeiro RM, Dias LAS, Berger PG and Dias DCFS (2011) Agroenergia na mitigação das mudanças climáticas globais, na segurança energética e na promoção social. Suprema, Viçosa, 203p.

Roscoe R (2008) Oleaginosas para a produção de biodiesel no Brasil: opções e alternativas. In Conbien, Uberlandia, 10p.

Sediyama T, Teixeira RC and Barros HB (2009) Origem, evolução e importância econômica. In Sediyama $\mathrm{T}$ (ed.) Tecnologia de produção e usos da soja. Mecenas, Londrina, p.1-6.

USDA - U. S. Department of Agriculture (2011) USDA agricultural projections to $\mathbf{2 0 2 0}$. USDA, Interagency Agricultural Projections Committee, Washington, 100p. (Longterm Projections Report OCE-2011-1) 